\title{
Diagnostic value of synovial fluid microscopy: a reassessment and rationalisation
}

\author{
A J Freemont, J Denton, A Chuck, P J L Holt, M Davies
}

\begin{abstract}
This study is in two parts. In the first synovial fluid from 1892 patients with 14 different arthropathies was examined microscopically. Crystals of different types were identified and the disease distribution of these and various cell types, including several not previously reported in synovial fluid, have been described. These features have been used to derive a series of microscopic diagnostic criteria for each arthropathy.

The criteria have been used in the second part of the study to examine synovial fluids from 200 patients without knowledge of any clinical diagnosis. Cytological and clinical diagnoses were compared at the end of the study. Matching diagnoses were made in 71 (35.5\%) and a short list of differential diagnoses (based on cytological criteria), which included the clinical diagnosis, was made in a further $43(21.5 \%)$. Of the rest, 63 $(31.5 \%)$ were correctly described as inflammatory or non-inflammatory and in five (2.5\%) no diagnosis could be made. Only in seven cases $(3 \cdot 5 \%)$ was an inaccurate (false positive) cytological diagnosis made.

The results indicate that synovial fluid microscopy is a potentially more important diagnostic screening test in rheumatological and orthopaedic practice than it would at first appear from published reports.
\end{abstract}

There are many published descriptions of the microscopic analysis of synovial fluid from normal and diseased joints. ${ }^{1-4}$ Various cell types have been identified in synovial fluid, including neutrophils, lymphocytes, immunoblasts, 5 ragocytes, ${ }^{6}$ eosinophils, ${ }^{7}$ and LE cells ${ }^{8}$ together with a diversity of crystals. ${ }^{1-4}$ Surveys have suggested that despite the potential of synovial fluid microscopic analysis it is rarely undertaken and when attempted is often done in a way that limits the potential information of the technique. In the section of osteoarticular pathology of the university department of rheumatology we have routinely analysed specimens of synovial fluid for 14 years, and our experience from between 8000 and 8500 analyses has suggested that synovial fluid microanalysis is potentially a more useful diagnostic investigation than has been previously recorded.

In this study we analysed synovial fluids from 1892 patients, from whom clinical follow up of more than three years was available, using techniques which could be routinely used in any pathology laboratory. From these data we derived a scheme for the analysis of any synovial specimen. We tested this scheme in a blind prospective study.

\section{Methods}

ESTABLISHMENT OF AN ANALYTICAL SCHEME

Patients

Synovial fluid was aspirated from the knees of 1892 adult patients with the following 14 clinical diagnoses (figures in parentheses refer to the number of patients in each group):

(i) seropositive rheumatoid disease (408);

(ii) seronegative rheumatoid disease (125);

(iii) primary generalised osteoarthritis (69);

(iv) monoarticular osteoarthritis (364);

(v) gout (198);

(vi) calcium pyrophosphate deposition disease (109);

(vii) septic arthritis (68);

(viii) internal derangement-for example, torn meniscus (121);

(ix) reactive arthritis (119);

(x) the peripheral arthritis associated with ankylosing spondylitis (110);

(xi) Reiter's syndrome (85);

(xii) inflammatory bowel disease (23);

(xiii) systemic lupus erythematosus (11);

(xiv) psoriasis (82).

All diagnoses were based on standard clinical, radiological, and serological criteria supported, where essential, by crystallographic and bacteriological examination of synovial fluid or synovium, or both.

Briefly, these criteria are: rheumatoid disease-as defined by the revised American Rheumatism Association (ARA) criteria9; systemic lupus erythematosus-at least four ARA criteria ${ }^{10}$; septic arthritis-culture of organism from synovial fluid or synovium, or both; gout-presence of sodium urate crystals in joint; calcium pyrophosphate deposition disease-monoarthropathy in which the synovial fluid contained an average of more than one intracellular calcium pyrophosphate crystal per $50 \times$ oil immersion objective field area in a routine unstained preparation (see below); internal derangement-meniscal or cruciate ligament tear associated with recurrent or continuous joint swelling for more than three months proved arthroscopically; reactive arthritis-development of oligoarthropathy in association with gastrointestinal or urinary tract infection but with no demonstrable organism in the joint; ankylosing spondylitis-radiological or clinical evidence, or both, of sacroiliitis or spinal ankylosis, or both, in HLA-B27 positive patients; Reiter's syndrome-only patients with 
the triad of non-specific urethritis, arthritis, and conjunctivitis were included in this group; psoriatic arthritis_established typical psoriatic skin lesions and an associated seronegative oligoarthropathy or polyarthropathy; monoarticular osteoarthritis-radiological evidence of joint space narrowing with at least one of the following: subarticular bone sclerosis, cyst formation, or osteophytes, together with no history of previous inflammatory arthritis; arthropathy associated with inflammatory bowel diseaseseronegative arthritis in a patient with large bowel Crohn's disease or ulcerative colitis proved by biopsy.

Joints were aspirated between two days and nine weeks from the onset of local symptoms and signs. Of necessity patients in different disease groups were not matched for age, sex, or treatment, and because of the diversity of disease groups and the size of the study no attempt was made to subclassify the arthritis further by patients' symptoms or signs.

\section{Microscopy}

Synovial fluid samples received in $2 \mathrm{ml}$ lithium heparin (Teklab Medical Laboratories, Durham) bottles were examined in the following three ways within eight hours of aspiration:

(i) Wet preparation for crystals and tissue fragments. A few drops of fluid were spread on a microscope slide and examined for crystals, cartilage, and fibrocartilage fragments and ragocytes (phagocytic cells containing apple green cytoplasmic inclusions) in 'stopped down' transmitted light - that is, diffuse light produced by almost complete closure of the microscope condenser diaphragm. Sodium urate and calcium pyrophosphate crystals were differentiated by their signs between crossed polarising plates with an interposed interference plate ${ }^{11}$ and hydroxyapatite by examining fresh preparations in polarised light after instilling alizarin red under the coverslip. (The hydroxyapatite/alizarin complex is both birefringent and red.) Ragocytes were counted and their number expressed as a percentage of all leucocytes per unit volume of synovial fluid (see below).

(ii) Total nucleated cell count. A measured aliquot of agitated synovial fluid was diluted in a $0.01 \% \mathrm{w} / \mathrm{v}$ solution of methyl violet $6 \mathrm{~B}$ in normal saline and the total number of nucleated cells per unit volume of fluid was established by counting stained nucleated cells in a FuchsRosenthal counting chamber. Fluids with total nucleated cell counts greater than $0.4 \times 10^{9} / 1$ were diluted with normal saline to an optimal concentration of about $0.4 \times 10^{9}$ cells $/$.

(iii) Differential cell count. Cell monolayers were prepared from diluted fluid by cytocentrifugation. These were fixed in methanol, stained using a standard Jenner-Giemsa technique, and mounted in synthetic mounting medium. Cells were identified by the criteria detailed below and their presence noted, and the more abundant were counted and their number expressed as a percentage of the first 500 nucleated cells encountered in random fields of the cytospin preparation.
All three stages take little time and a full analysis can, if requested, be made available within two hours of aspiration.

\section{Data analysis and production of algorithm}

The data for cell and crystal distribution were analysed to identify criteria specific for the different arthropathies and for groups of disorders. From these an analytical scheme (algorithm) was designed which could be applied to the examination of all synovial fluids.

ASSESSMENT OF THE ANALYTICAL SCHEME

Two hundred sequential synovial fluids from patients with established clinical diagnoses were sent to the laboratory in lithium heparin bottles as before, but the only clinical data made available were the patient's name, sex, age, and hospital number. The fluids were processed as before, and after microscopic examination the data derived were processed through the algorithm. On the basis of this each patient was assigned a cytological diagnosis which fell into one of the five following groups: $(a)$ no diagnosis possible; $(b)$ either an inflammatory or a non-inflammatory arthropathy; $(c)$ one of a short list of differential diagnoses; $(d)$ a short list of differential diagnoses with single favoured diagnosis; $(e)$ an exact diagnosis.

At the end of the study the clinical and cytological diagnoses were compared and the accuracy of cytological diagnosis assessed.

\section{Results}

ANALYSIS OF CRYSTALS, TISSUE FRAGMENTS, AND ORGANISMS

Crystals of sodium urate were only ever found in inflammatory arthropathies and were taken as being diagnostic of gout.

Crystals of hydroxyapatite were found only in osteoarthritis (328 of the 433 cases $(76 \%)$ ) and rheumatoid arthritis (82 of the 633 cases (13\%)).

Crystals of calcium pyrophosphate were seen in synovial fluids with cell counts $>1.5 \times 10^{9} / 1$ (inflammatory type-see below), a pattern consistent with pseudogout, but were also seen (in much smaller quantities) in non-inflammatorytype fluids $\left(<1 \times 10^{9}\right.$ cells $\left./ 1\right)$. This was interpreted as being from joints with a noninflammatory arthropathy and coincidental chondrocalcinosis.

In every case of septic arthritis that fulfilled the diagnostic criteria used in this study organisms were identified microscopically in the fluid.

Fragments of fibrocartilage were seen in cases of longstanding internal derangement and cartilage in patients with osteoarthritis.

\section{SYNOVIAL FLUID CYTOANALYSIS}

The following cell types were clearly differentiated in cytocentrifuge/wet preparations using simple morphology. As some can be considered morphological variants of others certain cell types have been grouped together. The disease distribution of all these cells has been analysed 
Table 1 Disease distribution of nucleated cells, ragocytes, polymorphs, and lymphocytes. Results shown as percentage of cases in each disease group with the features specified. Cytological features characteristic of one, or a small group of related arthropathies are underlined

\begin{tabular}{|c|c|c|c|c|c|c|}
\hline & \multicolumn{2}{|c|}{$\begin{array}{l}\text { Nucleated cells } \\
\left(\times 10^{9} / l\right)\end{array}$} & \multirow{2}{*}{$\begin{array}{l}\text { Ragocytes } \\
>65 \%\end{array}$} & \multicolumn{2}{|c|}{ Polymorphs } & \multirow{2}{*}{$\begin{array}{l}\text { Lymphocytes } \\
>80 \%\end{array}$} \\
\hline & $<1.5$ & $>25$ & & $<30 \%$ & $>80 \%$ & \\
\hline Septic arthritis & 0 & 74 & 44 & $\mathbf{0}$ & 100 & 0 \\
\hline Seropositive RA† & 2 & 12 & $\underline{32}$ & 11 & 46 & $\underline{9}$ \\
\hline $\begin{array}{l}\text { Seronegative RA } \\
\text { Ankylosing spondylitis } \\
\text { Reiter's syndrome }\end{array}$ & $\begin{array}{r}4 \\
9 \\
22\end{array}$ & $\begin{array}{l}0 \\
0 \\
5\end{array}$ & $\begin{array}{l}\mathbf{0} \\
\mathbf{0} \\
\mathbf{0}\end{array}$ & $\begin{array}{r}8 \\
0 \\
24\end{array}$ & $\begin{array}{l}39 \\
53 \\
38\end{array}$ & $\begin{array}{l}0 \\
0 \\
\underline{9}\end{array}$ \\
\hline Reactive arthritis & 2 & 22 & 0 & 42 & 11 & $\underline{7}$ \\
\hline $\begin{array}{l}\text { Psoriasis } \\
\text { Inflammatory bowel disease } \\
\text { SLE } \dagger\end{array}$ & $\begin{array}{r}9 \\
4 \\
36\end{array}$ & $\begin{array}{l}7 \\
9 \\
0\end{array}$ & $\begin{array}{l}\mathbf{0} \\
\mathbf{0} \\
\mathbf{0}\end{array}$ & $\begin{array}{l}20 \\
39 \\
45\end{array}$ & $\begin{array}{r}20 \\
13 \\
9\end{array}$ & $\begin{array}{r}0 \\
0 \\
18\end{array}$ \\
\hline $\begin{array}{l}\text { Gout } \\
\text { CPPD }\end{array}$ & $\begin{array}{l}32 \\
41\end{array}$ & $\begin{array}{l}4 \\
0\end{array}$ & $\begin{array}{l}0 \\
0\end{array}$ & $\begin{array}{l}18 \\
40\end{array}$ & $\begin{array}{l}36 \\
40\end{array}$ & $\begin{array}{l}0 \\
0\end{array}$ \\
\hline Generalised osteoarthritis & $\underline{100}$ & 0 & 0 & 88 & 0 & 0 \\
\hline Monoarticular osteoarthritis & $\underline{100}$ & 0 & 0 & 93 & 0 & $\underline{14}$ \\
\hline Internal derangement & $\underline{100}$ & 0 & 0 & 100 & 0 & 0 \\
\hline
\end{tabular}

$\lceil\mathrm{RA}=$ rheumatoid arthritis; $\mathrm{SLE}=$ systemic lupus erythematosus; $\mathrm{CPPD}=$ calcium pyrophosphate deposition disease.

Table 2 Distribution of non-lymphoid mononuclear cells and mast cells. Results shown as percentage of cases in each disease group with the features specified. Cytological features characteristic of one, or a small group of related arthropathies are underlined

\begin{tabular}{|c|c|c|c|c|c|c|c|}
\hline & \multirow{2}{*}{$\begin{array}{l}M N C^{*} \\
>60 \%\end{array}$} & \multicolumn{2}{|l|}{$C P M^{*}$} & \multicolumn{2}{|l|}{$R M N^{*}$} & \multicolumn{2}{|c|}{ Mast cells } \\
\hline & & Present & $>10 \%$ & Present & $>50 \%$ & Present & with $C P M$ \\
\hline Septic arthritis & 0 & 0 & 0 & 0 & 0 & $\mathbf{0}$ & 0 \\
\hline $\begin{array}{l}\text { Seropositive RA† } \\
\text { Seronegative RA } \\
\text { Ankylosing spondylitis }\end{array}$ & $\begin{array}{l}0 \\
0 \\
0\end{array}$ & $\begin{array}{l}16 \\
14 \\
26\end{array}$ & $\begin{array}{l}0 \cdot 5 \\
0 \\
\underline{13}\end{array}$ & $\begin{array}{l}11 \\
14 \\
13\end{array}$ & $\begin{array}{l}0 \\
0 \\
0\end{array}$ & $\begin{array}{r}7 \\
14 \\
27\end{array}$ & $\begin{array}{r}0 \\
0 \\
20 \\
\end{array}$ \\
\hline Reiter's syndrome & 0 & 57 & $\underline{19}$ & 14 & 0 & 34 & $\underline{24}$ \\
\hline Reactive arthritis & $\underline{5}$ & 69 & $\underline{47}$ & 26 & 0 & 11 & $\underline{9}$ \\
\hline Psoriasis & $\underline{5}$ & 40 & $\underline{13}$ & 26 & 0 & 40 & $\underline{13}$ \\
\hline Inflammatory bowel disease & 0 & 52 & $\underline{22}$ & 13 & 0 & 48 & $\underline{22}$ \\
\hline SLE† & 18 & 0 & $\overline{0}$ & 27 & 0 & 18 & $\overline{0}$ \\
\hline $\begin{array}{l}\text { Gout } \\
\text { CPPD }\end{array}$ & $\begin{array}{r}6 \\
20\end{array}$ & $\begin{array}{l}32 \\
20\end{array}$ & $\begin{array}{l}4 \\
0\end{array}$ & $\begin{array}{l}11 \\
20\end{array}$ & $\begin{array}{r}4 \\
10\end{array}$ & $\begin{array}{l}14 \\
10\end{array}$ & $\begin{array}{l}5 \\
0\end{array}$ \\
\hline Generalised osteoarthritis & 66 & $\underline{11}$ & 0 & 88 & 33 & 11 & 0 \\
\hline Monoarticular osteoarthritis & 32 & 6 & 0 & 60 & 11 & 41 & $\underline{2}$ \\
\hline Internal derangement & 5 & 0 & 0 & 68 & 8 & 46 & 0 \\
\hline
\end{tabular}

${ }^{*} \mathrm{MNC}=$ monocytoid mononuclear cells; $\mathrm{CPM}=$ cytophagocytic monocytes; $\mathrm{RMN}=$ round mononuclear cells; $\mathrm{RA}=$ rheumatoid arthritis; SLE=systemic lupus erythematosus; $C P P D=$ calcium pyrophosphate deposition disease.

Table 3 Disease distribution of eosinophils (Eosin), LE cells, tart cells $(T C)$, plasma cells $(P C)$, Reider cells (RC), multinucleate cells (Mult), Mott cells $(M C)$, cells in mitosis (Mit), and cells containing Döhle's bodies $(D B)$. Results shown as percentage of cases in each disease group with the features specified. Cytological features characteristic of one, or a small group of related arthropathies are underlined

\begin{tabular}{|c|c|c|c|c|c|c|c|c|c|}
\hline & Eosin & $L E$ & $T C$ & $P C$ & $R C$ & Mult & $M C$ & Mit & $D B$ \\
\hline Septic arthritis & 0 & 0 & 0 & 0 & 0 & 0 & 0 & 0 & 0 \\
\hline Seropositive RA† & 5 & $\underline{3}$ & $\underline{2}$ & 1 & $\underline{6}$ & $\underline{3}$ & $\underline{3}$ & $\underline{4}$ & $\underline{3}$ \\
\hline $\begin{array}{l}\text { Seronegative RA } \\
\text { Ankylosing spondylitis } \\
\text { Reiter's syndrome }\end{array}$ & $\begin{array}{r}8 \\
13 \\
0\end{array}$ & $\begin{array}{r}0 \\
0 \\
14 \\
\end{array}$ & $\begin{array}{l}0 \\
0 \\
0\end{array}$ & $\begin{array}{l}0 \\
0 \\
0\end{array}$ & $\begin{array}{l}\mathbf{0} \\
\mathbf{0} \\
\mathbf{0}\end{array}$ & $\begin{array}{l}0 \\
0 \\
0\end{array}$ & $\begin{array}{l}0 \\
0 \\
0\end{array}$ & $\begin{array}{l}0 \\
0 \\
0\end{array}$ & $\begin{array}{l}0 \\
0 \\
0\end{array}$ \\
\hline Reactive arthritis & 16 & 0 & 0 & 9 & 0 & 0 & 0 & $\underline{9}$ & 0 \\
\hline Psoriasis & 20 & $\underline{7}$ & $\mathbf{0}$ & 7 & 0 & $\underline{7}$ & 0 & $\underline{26}$ & 0 \\
\hline $\begin{array}{l}\text { Inflammatory bowel disease } \\
\text { SLE† }\end{array}$ & $\begin{array}{r}9 \\
18\end{array}$ & $\begin{array}{r}0 \\
\underline{45} \\
\end{array}$ & $\begin{array}{l}\mathbf{0} \\
\mathbf{0}\end{array}$ & $\begin{array}{l}\mathbf{0} \\
\mathbf{0}\end{array}$ & $\begin{array}{l}\mathbf{0} \\
\mathbf{0}\end{array}$ & $\begin{array}{l}\mathbf{0} \\
\mathbf{0}\end{array}$ & $\begin{array}{l}0 \\
0\end{array}$ & $\begin{array}{l}\mathbf{0} \\
\mathbf{0}\end{array}$ & $\begin{array}{l}0 \\
0\end{array}$ \\
\hline $\begin{array}{l}\text { Gout } \\
\text { CPPD* }\end{array}$ & $\begin{array}{r}0 \\
10\end{array}$ & $\begin{array}{l}\mathbf{0} \\
\mathbf{0}\end{array}$ & $\begin{array}{l}0 \\
0\end{array}$ & $\begin{array}{l}4 \\
0\end{array}$ & $\begin{array}{l}\mathbf{0} \\
\mathbf{0}\end{array}$ & $\begin{array}{l}4 \\
0\end{array}$ & $\begin{array}{l}0 \\
0\end{array}$ & $\begin{array}{l}4 \\
0\end{array}$ & $\begin{array}{l}0 \\
0\end{array}$ \\
\hline Generalised osteoarthritis & $\underline{11}$ & 0 & $\mathbf{0}$ & $\mathbf{0}$ & 0 & $\underline{23}$ & 0 & $\underline{11}$ & 0 \\
\hline Monoarticular osteoarthritis & $\underline{14}$ & $\underline{7}$ & $\mathbf{0}$ & 0 & $\underline{1}$ & $\underline{3}$ & 0 & $\underline{6}$ & 0 \\
\hline Internal derangement & $\overline{0}$ & $\overline{0}$ & $\mathbf{0}$ & $\mathbf{0}$ & 0 & $\overline{0}$ & 0 & $\overline{0}$ & 0 \\
\hline
\end{tabular}

†RA=rheumatoid arthritis; SLE=systemic lupus erythematosus; $C P P D=$ calcium pyrophosphate deposition disease. 
and some measured. Tables $1-3$ record the most pertinent data.

In the following descriptions each cell is named and if necessary described. After the description is a short section in parentheses which includes the table in which the disease distribution is defined and the method of measurement outlined (usually either recorded simply as present or absent or expressed as a proportion of another group of cells).

(1) Neutrophil polymorphs (table 1-expressed as a percentage of all nucleated cells).

(2) Lymphocytes and lymphocyte derived cells.

(a) Small lymphocytes (table 1-expressed as a percentage of nucleated cells).

(b) Plasma cells (table 3-not quantified-that is, only recorded as present or absent).

(c) Reider cells-cells with a nuclear to cytoplasmic ratio $>70 \%$ and multilobed nuclei, the lobes showing symmetry about a pale attenuated central region (fig 1A). The morphology of these cells is identical to Reider cells previously described in blood smears ${ }^{12}$ (table 3-not quantified-either present or absent).

(d) Mott cells_-cells resembling plasma cells with large numbers of Russell bodytype cytoplasmic inclusions ${ }^{13}$ (fig 1B) (table 3-not quantified-either present or absent).

(3) Large mononuclear cells-three morphologically defined subgroups of cells within this category (not recorded as a single group in the tables).

(a) Monocytoid mononuclear cells-cells more than $13 \mu \mathrm{m}$ in diameter with a nuclear to cytoplasmic ratio $>50 \%$ and
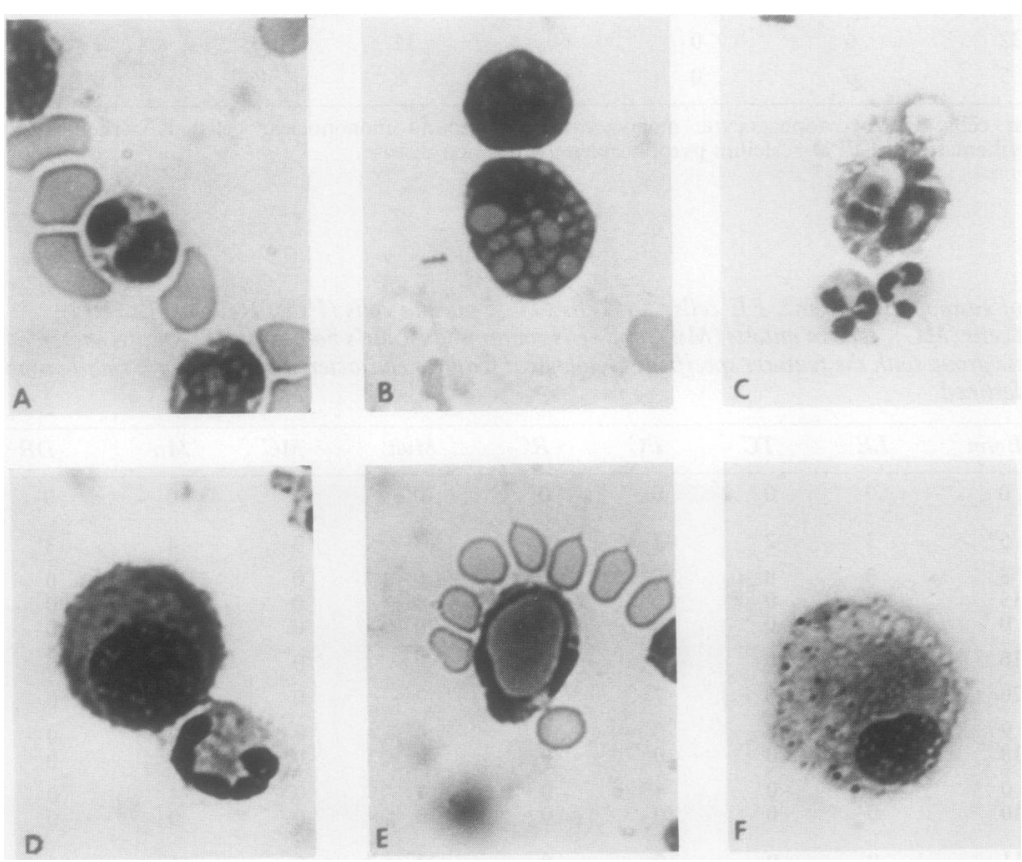

Figure 1 Various cells in synovial fluid. (A) Reider cells with bilobed nuclei; (B) a Mot cell with large round cytoplasmic inclusions; $(c)$ a cytophagocytic macrophage with a cell with large round cytoplasmic inclusions; (c) a cytophagocytic macrophage with a
recognisable polymorph in its cytoplasm; $(D)$ a round mononuclear cell, note the cytoplasmic frill; $(E)$ an $L E$ cell with a single large amorphous inclusion; $(F)$ a ragocyte. irregular and sometimes vacuolated nuclei (table 2-expressed as a percentage of nucleated cells).

(b) Cytophagocytic monocytes-monocytoid mononuclear cells which contain phagocytosed whole neutrophils or recognisable neutrophil nuclei (fig 1C) (table 2-expressed either as present or absent or, if enough, as a percentage of all large mononuclear cells).

(c) Round mononuclear cells-a subgroup of large mononuclear cells was also recognised which had a somewhat smaller, rounder, and denser nucleus than other large mononuclear cells, granular basophilic cytoplasm, and a nuclear to cytoplasmic ratio $<50 \%$. These cells have an appearance similar to that of synoviocytes. ${ }^{14}$ We have designated them large monocytoid mononuclear cells with round nuclei (fig 1D) (table 2-expressed either as present or absent or, if enough, as a percentage of nucleated cells).

(4) Eosinophils (table 3-not quantifiedeither present or absent).

(5) Mast cells (table 2-not quantifiedeither present or absent). Note: the presence of both mast cells and cytophagocytic monocytes in one fluid is an important index.

(6) Multinucleate cells_-osteoclast-like polykarions with a variable number of nuclei (table 3 -not quantified-either present or absent). (Multinucleated plasma cells are not included in this group.)

(7) Cells in mitosis (table 3-not quantified-either present or absent).

(8) Groups of cells, either polymorphs or monocytoid mononuclear cells, which have distinctive cytoplasmic inclusions.

(a) LE cells-phagocytic cells (neutrophils or monocytoid mononuclear cells) containing large or small cytoplasmic inclusions of nuclear material with no recognisable chromatin pattern (fig $1 E$ ) (table 3-not quantified-either present or absent).

(b) Tart cells-cells with an appearance very similar to that of $L E$ cells but with a recognisable chromatin pattern within the intracytoplasmic nuclear inclusions (table 3-not quantified-either present or absent). These cells are identical to the tart cells seen in peripheral blood. ${ }^{13}$

(c) Döhle's body cells-cells (monocytoid mononuclear cells and polymorphs) containing duck egg blue cytoplasmic inclusions up to $5 \mu \mathrm{m}$ in diameter (table 3-not quantified-either present of absent). These inclusions resemble Döhle's bodies ${ }^{15}$ _inclusions found in peripheral blood cells in patients with a variety of systemic disorders.

(d) Ragocytes-phagocytic cells (monocytoid mononuclear cells or polymorphs) which in 'stopped down' transmitted illumination contain apple-green, rather coarse cytoplasmic inclusions (fig $1 F$ ) (table 1-expressed as a percentage of nucleated cells). 
It will be seen that most of the cell types were found in fluids from at least some patients in every disease group. The absolute number and proportion of each cell type varied considerably within and between disease groups, however. The diseases fall into four clinical categoriesseptic arthritis, primary inflammatory arthritis, crystal arthritis, and non-inflammatory arthropathies. These categories are grouped separately in the tables. By cytological examination of the fluid it was possible to distinguish between inflammatory and non-inflammatory arthropathies in all but seven cases. Non-inflammatory arthropathies had either synovial fluid nucleated cell counts of less than $10^{9} / 1$ or between $10^{9}$ and $1.5 \times 10^{9}$ cells/ 1 with a predominance of lymphocytes or large mononuclear cells, or both, whereas in fluids from patients with inflammatory disorders cell counts were either greater than $1.5 \times 10^{9} / 1$ or if the number of cells lay between $10^{9}$ and $1.5 \times 10^{9}$ cells $/ 1$ more than $50 \%$ of the cells were polymorphs.

When individual diseases were studied variation in cell number and type was seen between patients in the same clinical groups. Thus whereas most patients with rheumatoid disease had a high proportion of polymorphs in their synovial fluids, aspirates from a small number (9\%) contained a very high proportion of lymphocytes. Despite this variation within diseases there were some cytological features characteristic of one, or a small group of related, arthropathies. These are underlined in the tables. For instance, provided that crystal induced and septic arthritis had been excluded (see below), only in fluids from patients with seropositive rheumatoid disease were more than

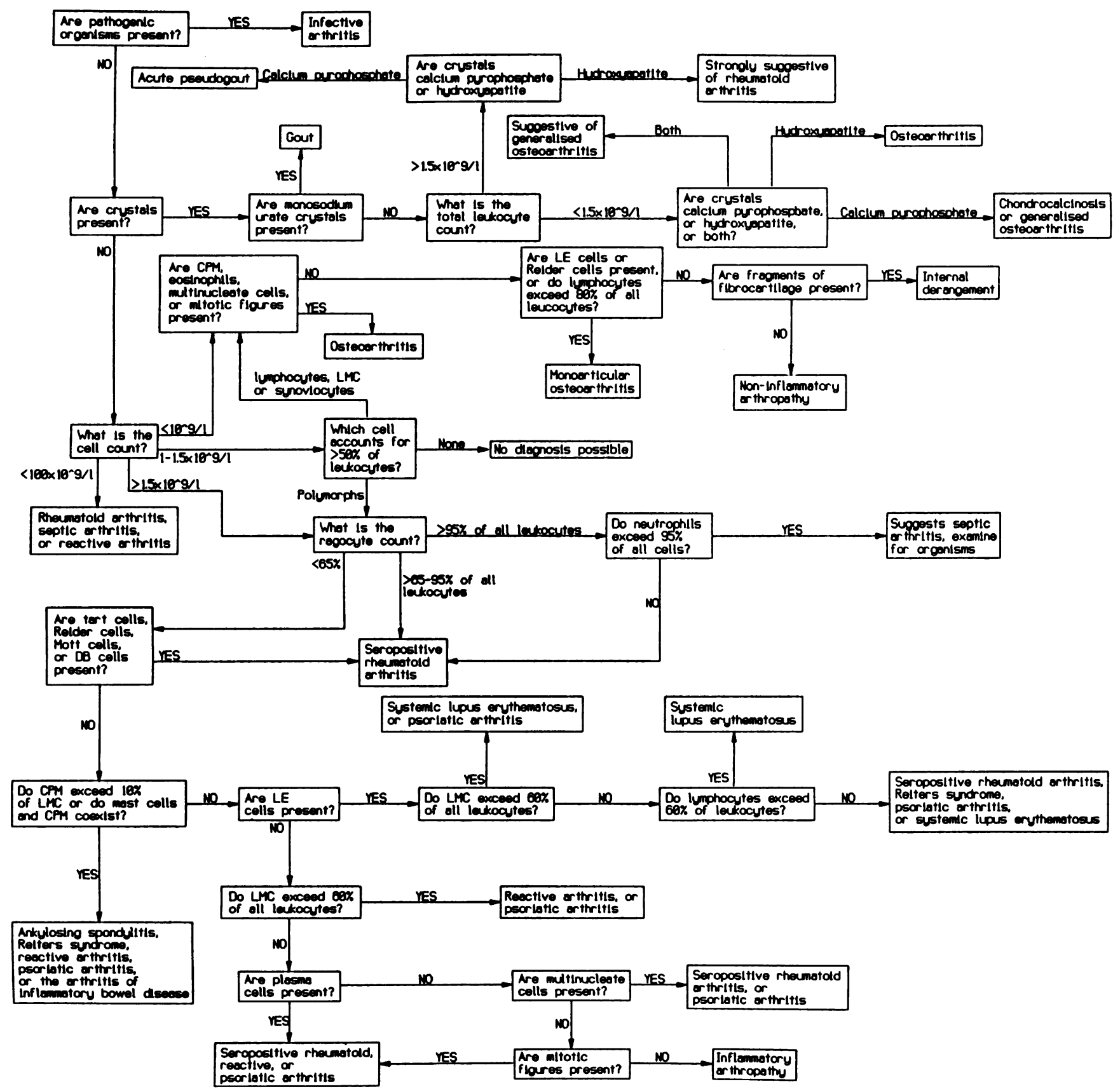

Figure 2 Algorithm for the analysis of observations derived from synovial fluid microscopy. DB=Döhle's body cells; CPM=cytophagocytic monocytes; $L M C=$ large mononuclear cells. 
Table 4 Comparison of clinical and cytological diagnoses

\begin{tabular}{|c|c|c|c|c|c|c|c|c|c|c|}
\hline \multirow{3}{*}{$\begin{array}{l}\text { Clinical } \\
\text { diagnosis }\end{array}$} & \multirow[t]{3}{*}{$n$} & \multicolumn{9}{|c|}{ Cytological diagnosis type $e^{*}$} \\
\hline & & \multicolumn{2}{|l|}{$A$} & \multicolumn{2}{|l|}{$\boldsymbol{B}$} & \multicolumn{2}{|l|}{$C$} & \multicolumn{2}{|l|}{$D$} & \multirow[t]{2}{*}{$E$} \\
\hline & & $R t$ & $W t$ & $\boldsymbol{R}$ & $W$ & $R$ & $\boldsymbol{W}$ & $R$ & $W$ & \\
\hline $\begin{array}{l}\text { Septic arthritis } \\
\text { Seropositive positive RA } \\
\text { Seronegative RA } \\
\text { Ankylosing spondylitis } \\
\text { Reiter's syndrome } \\
\text { Reactive arthritis } \\
\text { Psoriasis } \\
\text { Inflammatory bowel disease } \\
\text { SLE } \neq \\
\text { Gout } \\
\text { CPPD } ¥ \\
\text { Generalised osteoarthritis } \\
\text { Monoarticular osteoarthritis } \\
\text { Internal derangement }\end{array}$ & $\begin{array}{r}19 \\
57 \\
11 \\
3 \\
6 \\
26 \\
26 \\
2 \\
1 \\
1 \\
23 \\
6 \\
4 \\
4 \\
26 \\
15\end{array}$ & $\begin{array}{r}14 \\
21 \\
0 \\
0 \\
0 \\
0 \\
0 \\
0 \\
0 \\
23 \\
6 \\
0 \\
2 \\
5\end{array}$ & $\begin{array}{l}0 \\
0 \\
1 \\
0 \\
0 \\
0 \\
0 \\
0 \\
0 \\
0 \\
0 \\
0 \\
0 \\
0\end{array}$ & $\begin{array}{l}4 \\
7 \\
0 \\
0 \\
0 \\
0 \\
0 \\
0 \\
0 \\
0 \\
0 \\
0 \\
0\end{array}$ & $\begin{array}{l}0 \\
1 \\
1 \\
0 \\
0 \\
1 \\
0 \\
0 \\
0 \\
0 \\
0 \\
0 \\
0 \\
0\end{array}$ & $\begin{array}{r}0 \\
9 \\
0 \\
2 \\
2 \\
12 \\
1 \\
0 \\
1 \\
0 \\
0 \\
1 \\
14 \\
1\end{array}$ & $\begin{array}{l}0 \\
1 \\
0 \\
0 \\
0 \\
0 \\
0 \\
0 \\
0 \\
0 \\
0 \\
1 \\
0 \\
0\end{array}$ & $\begin{array}{r}1 \\
16 \\
8 \\
1 \\
4 \\
12 \\
1 \\
1 \\
0 \\
0 \\
0 \\
1 \\
9 \\
9\end{array}$ & $\begin{array}{l}0 \\
0 \\
0 \\
0 \\
0 \\
0 \\
0 \\
0 \\
0 \\
0 \\
0 \\
1 \\
0 \\
0\end{array}$ & $\begin{array}{l}0 \\
2 \\
1 \\
0 \\
0 \\
1 \\
0 \\
0 \\
0 \\
0 \\
0 \\
0 \\
1 \\
0\end{array}$ \\
\hline $\begin{array}{l}\text { Total No } \\
\text { Total \% }\end{array}$ & $\begin{array}{l}200 \\
100\end{array}$ & $\begin{array}{l}71 \\
35 \cdot 5\end{array}$ & $\begin{array}{l}1 \\
0.5\end{array}$ & ${ }_{5 \cdot 5}^{11}$ & $\begin{array}{l}3 \\
1.5\end{array}$ & $\begin{array}{l}43 \\
21 \cdot 5\end{array}$ & $\begin{array}{l}2 \\
1\end{array}$ & $\begin{array}{l}63 \\
31 \cdot 5\end{array}$ & $\begin{array}{l}1 \\
0.5\end{array}$ & $\begin{array}{l}5 \\
2 \cdot 5\end{array}$ \\
\hline
\end{tabular}

${ }^{*} \mathrm{~A}=$ single cytological diagnosis given; $\mathrm{B}=$ single cytological diagnosis suggested from short list; $\mathrm{C}=$ short list of specific cytological diagnoses given; $\mathrm{D}=$ synovial fluid assigned as inflammatory or non-inflammatory joint disease only; $\mathrm{E}=$ no diagnosis possible diagnoses given; $D=$ synovial fluid assigned

$\ddagger R A=$ rheumatoid arthritis; SLE =systemic lupus erythematosus; $C P P D=$ calcium pyrophosphate deposition disease.

$65 \%$ of the nucleated cell ragocytes and only in osteoarthritis and internal derangements were more than $50 \%$ of the nucleated cells round mononuclear cells - that is, probable synoviocytes; more than $10 \%$ cytophagocytic monocytes was characteristic of the peripheral arthropathy associated with ankylosing spondylitis, Reiter's disease, psoriasis, inflammatory bowel disease, or reactive arthropathy (these five diseases were also the only primary inflammatory synovitides in which mast cells and cytophagocytic monocytes occurred together); cells containing Döhle's bodies, tart cells, Mott cells, and Reider cells were characteristic of seropositive rheumatoid disease; and in the group of non-inflammatory arthropathies the synovial fluid in osteoarthritis, as distinct from internal derangements, contained cytophagocytic monocytes, eosinophils, multinucleate cells, and cells in mitoses or showed a marked predominance of lymphocytes $(>80 \%$ of leucocytes).

Although characteristic of certain clinical groups these features were usually encountered in a proportion only of the members of that group-for example, ragocyte counts of $65 \%$ of all leucocytes, though characteristic of seropositive rheumatoid arthritis, were found in only $32 \%$ of the patients.

Those characteristics that were considered to be of potential diagnostic value (underlined in tables 1-3) were extracted from the data and used to develop an algorithm (fig 2) for the analysis of observations derived from synovial fluid microscopy including cytoanalysis. The algorithm was used to analyse microscopy data obtained from the 200 fluids in the second part of the study. Table 4 gives these results.

These data show that at the end of the blind trial a single cytological diagnosis was made in 72 cases (type $A$ in table 4 ) and in 71 it matched the clinical diagnosis exactly (AR). In 14 cases cytoanalysis suggested a single cytological diagnosis to be the most likely (type B in table 4) and, of these, 11 matched the clinical diagnosis (BR). In 45 cases short lists of differential diagnoses (type $\mathrm{C}$ in table 4 ) were made, which in 43 cases contained the clinical diagnosis (CR). In 64 cases the diagnosis could be advanced no further than saying the patients had either an inflammatory or a non-inflammatory arthropathy (type D in table 4) and, of these, 63 matched the type of arthropathy defined clinically. In five cases no diagnosis could be made cytologically (type $E$ in table 4 ).

Thus in $62.5 \%$ of the cases a more or less accurate working diagnosis was made on the basis of microscopic analysis of the synovial fluid alone (AR+BR+CR) and in a further $31.5 \%$ (DR) the patient was correctly identified as having either an inflammatory or non-inflammatory arthropathy. Of the $6 \%$ of cases in which either an inaccurate diagnosis $(A W+B W+C W+D W)$ or no diagnosis $(E)$ was made, many of the inaccuracies were minor. For instance, in one case the diagnosis of seropositive rheumatoid disease was made on a patient who had seronegative rheumatoid disease (a second case in which this happened seroconverted 13 months later).

\section{Discussion}

In this study we have shown that a mixture of careful qualitative and quantitative macroscopic analyses of synovial fluid can identify differences and emphasise similarities between the various common diseases which constitute each of the major categories of arthritis. When comparison is made within and between clinically defined groups of patients it is clear that certain cytological features are unique to individual arthropathies, whereas other clinically distinct arthropathies share similar patterns of synovial fluid cell content. No cytological feature was seen in every patient in any one clinical group, and indeed in some groups there was considerable variation in the cell content of the synovial fluids between patients.

It is implicit in these observations that the balance between the various factors controlling the efflux of cells from synovium into synovial fluid may be unique to some arthropathies, may vary between the members of a disease group, 
or be similar in a variety of disorders. Similarities between different clinical groups might indicate common underlying pathogenic mechanisms within the joints. Variation within a single group might reflect differences in disease activity, treatment, joint use, etc, at the time of aspiration or may indicate the existence of true subgroups of that disease. Before the latter possibility can be seriously entertained it would be necessary to analyse each group more closely to establish the effects of those indices which were not controlled in this study. Even when these complicating factors are taken into account it would seem that detailed synovial fluid cytoanalysis offers a hitherto underexploited method of investigating the processes of arthritis. In particular, it might be useful for defining subgroups of patients for comparative study or in performing longitudinal studies on individual patients or cohort studies to compare the effects of different therapeutic regimens.

The blind cytoanalysis of 200 synovial fluid samples shows that the criteria outlined in the algorithm offer a diagnostic test for use in clinical practice. The techniques used are routine and are available in every cytopathology laboratory and many microbiology departments.

We believe this is the first study of this type to be reported, in which quantitative and qualitative synovial fluid microscopic data from patients with so many diseases have been compared and a straightforward analytical scheme proposed and tested.

Because of the patient selection criteria used in this study we have no doubt that a closer correlation of clinical and cytological data for patients in each group will lead to refinements of the algorithm that may have diagnostic or prognostic implications, or both. Nevertheless, because it is applicable to any patient with a joint effusion, could be undertaken currently in any hospital with a basic pathology service, and because results can be made available within two to three hours of aspiration we feel that even as it stands this method of assessing synovial fluid represents a useful basic screening test. We have used it for some time and find it valuable in rheumatological practice, particularly in assessing patients with oligo- and monoarthropathies. Discussion with our colleagues in other hospital specialties (general medicine, orthopaedics, geriatrics, etc) and general practitioners, all of whom are using the service increasingly frequently, has shown that they too feel this has positively altered patient management, offering particular advantages in diagnosis, for following up patients with joint disease, and in rationalising specialist referral policy.

This work was funded by the Arthritis and Rheumatism Council. The microscope used in this study was donated by the John Charnley Trust.

1 Revell P A. Examination of synovial fluid. Curr Top Pathol 1982; 71: 1-24.

2 Currey H L F, Vernon-Roberts B. Examination of synovial fluid. Clin Rheum Dis 1976; 2: 149-77.

3 Wolf A W, Benson D R, Shiji $\mathrm{H}$, et al. Current concepts in synovial fluid analysis. Clin Orthop 1978; 134: 261-5.

4 Naib Z M. Cytology of synovial fluids. Acta Cytol (Baltimore) 1973; 17: 299-314.

5 Eghtedari A A, Bacon P A, Collins A. Immunoblasts in synovial fluid and blood in the rheumatic diseases. Ann Rheum Dis 1980; 39: 318-22.

6 Hollander J L, McCarty D J, Astorga G, Castro-Murillo E. Studies on the pathogenesis of rheumatoid joint inflamStudies on the pathogenesis of rheumatoid joint inflam-
mation. I. The "RA cell" and a working hypothesis. Ann

Intern Med 1965; 62: 271-80.
7 Ropes M W, Bauer W. Synovial fluid changes in joint disease. Cambridge. Harvard University Press, 1953.

8 Hunder G G, Pierre $R$ V. In vivo $L E$ cell formation in synovial fluid. Arthritis Rheum 1970; 13: 448-54.

9 Arnett F C, Edworthy S M, Bloch D A, et al. The American Rheumatism Association 1987 revised criteria for the classification of rheumatoid arthritis. Arthritis Rheum 1988; 31: $315-24$

10 Tan E M, Cohen E S, Fries J, et al. Criteria for the classification of systemic lupus erythematosus. Arthritis
Rheum 1982; 25: 1271-80.

11 Dieppe P, Calvert P. Crystals and joint disease. London: Chapman and Hall, 1983.

12 Williams W J, Beutler E, Ersleu A J, Rundles R W. Haematology. New York: McGraw-Hill, 1972.

13 Besis M. Ultrastructure of lymphoid and plasma cells in relation to globulin and antibody formation. Lab Invest

1961; 10: 1040-9.
14 Trachof R B, Pascual E, Schumacher H R. Mononuclear cells in human synovial fluid. Arthritis Rheum 1976; 19: 743-8.

15 Döhle H. Leukocyteneinschluesse bei Scharlach. Zentraeblah fur Bakteriologie 1911; 61: 63-72. 